\title{
DESTRUCTION MECHANISM OF COASTAL LEVEES ON THT SENDAI BAY COAST HIT BY THE 2011 TSUNAMI
}

\author{
Akira Mano ${ }^{1}$, Hitoshi Tanaka ${ }^{2}$ and Keiko Udo ${ }^{3}$
}

\begin{abstract}
A mega tsunami hit the Sendai Bay Coast on March 11, 2011, overtopped coastal levees and intruded into far inland while sweeping houses, people and others away. Eighty percent of the levees which rimmed the coast to protect the land from storm surges together with the wind waves were broken in various degrees of damage by the tsunami. The national and local governments decided to rebuild the levees to be durable even for mega tsunamis. This requirement motivates us to find the destruction mechanism of the coastal levees. We conducted field investigations and collected the tsunami records, aerial photos and tsunami videos. Especially, the video taken from the helicopter "Michinokugo" which flew along the Sendai Coast to the south during the attack of the tsunami's leading wave enables us to see the breaking process. Integrated analysis leads to two step mechanisms of the destruction: the first step of breaking the upper structure of the levees by the surging bore of the leading wave and the second step of expanding erosion by the return flow concentration.
\end{abstract}

Keywords: durable levee; tsunami surge; return flow; flow concentration; breach

\section{INTRODUCTION}

The Great East Japan Earthquake of Mw 9.0 occurred with the epicenter $70 \mathrm{~km}$ off the Oshika Peninsula, Miyagi Prefecture, at 14:46 Japan Standard Time (JST) on March 11, 2011and accompanied a mega tsunami, the source area of which stretches from Iwate to Ibaragi with a length of $500 \mathrm{~km}$ and a width of $200 \mathrm{~km}$. The tsunami propagated first to the Sanriku Coast, then to Hokkaido and the Sendai Bay Coast, and finally to the whole Pacific Rim coasts even to the Antarctica Coast. The damage by the tsunami is especially high in the three prefectures close to the source area: Iwate Prefecture, Miyagi Prefecture, and Fukushima Prefecture (see Fig. 1). In most of these areas, the tsunami broke the coastal levees through by overtopping or fracturing, and intrude into far inland while sweeping houses, people and others away. The total casualties of dead and missing people by this tsunami reach 18.8 thousands, with 9.0 thousands for the Sendai Bay Coast; 8.0 thousands for the Sanriku Coast; 1.8 thousands for the Joban Coast of Fukushima Prefecture.
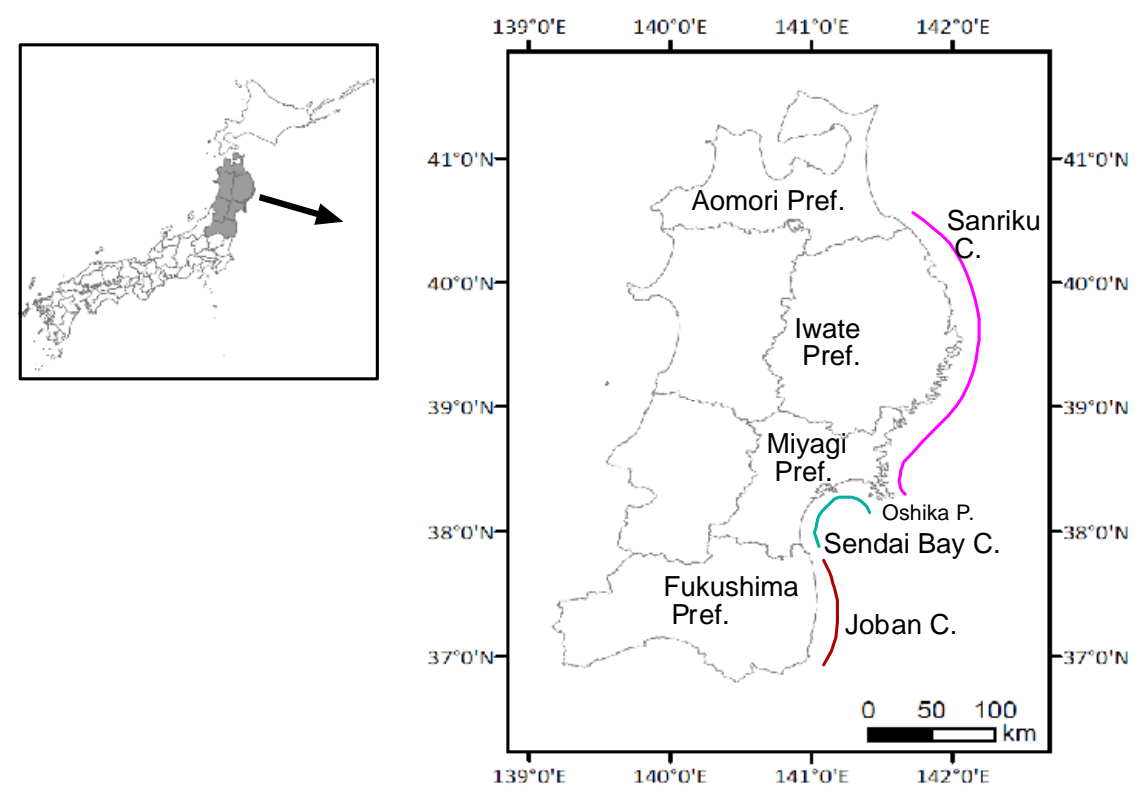

Figure 1. Most damaged coasts: the Sanriku Coast, the Sendai Bay Coast, and the Joban Coast.

\footnotetext{
${ }^{1}$ IRIDeS, Tohoku University, 6-6-11 Aramaki Aza-Aoba, Aoba-Ku, Sendai, 980-8579, Japan

${ }^{2}$ School of Engineering, Tohoku University, 6-6-11, Aramaki Aza-Aoba, Aoba-Ku, Sendai, 980-8579, Japan

${ }^{3}$ IRIDeS, Tohoku University, 6-6-11 Aramaki Aza-Aoba, Aoba-Ku, Sendai, 980-8579, Japan
} 
The Sendai Bay Coast is characterized by long sandy beaches with the alluvial plains in which big cities like Ishinomaki, Sendai, Natori, and Shiogama are developed. Ishinomaki city was evolved as a harbor town at the Kitakami River mouth and had dense population near the water front. The bay is shallow because of the sediment from big rivers and the Oshika peninsula functions as a breakwater to reduce the tsunamis off the Sanriku Coast. Therefore big tsunamis are significantly rare in the bay area. The previous big tsunamis are reported to be the 869 Jogan Tsunami and the 1611 Keicho Tsunami (Satake et al. 2007, Nanayama et al. 2003). The return period of the 2011 Tsunamis is estimated to be 500 to 1000 years. The major hazards for the coasts are storm surges and wind wave. To protect the hazards, coastal levees with the height of 6 to $7 \mathrm{~m}$ above the mean sea level rimed the coasts.

The inundation and run-up height above the mean sea level of the 2011 Tsunami in Fig. 2 reaches up to $15 \mathrm{~m}$ on the Sendai Bay Coast which is much less than that of the Sanriku Coast, but higher than the height of the coastal levees. The tsunami overtopped most part of the coastal levees in the bay area and intruded into far inland of the alluvial plains while sweeping houses, people, and others away. Dense population and unpreparedness of the people to evacuate for big tsunamis are the major reasons for the high human damage in the bay area in spite of the shorter coast lines and lower tsunami height in comparison with those of the Sanriku Coast. Eighty percent of the coastal levees on the Sendai Bay Coast were broken in various degrees of damage, ranging from dispersion of the frontal wave dissipation blocks to complete disappearance of the levee and beach.

The Miyagi prefectural government determined a rebuilt policy of the coastal levees based on the guide line of Ministry of Land, Infrastructure, Transport and Tourism (MLIT) and Ministry of Agriculture, Forestry and Fisheries such that the design tsunami for the levee rebuilt may have a return period of several decade years to one hundred and several decade years depending on the local conditions. This means that protection from mega tsunamis only by the levees is unrealistic from the viewpoint of the costs, maintenance, landscape, etc. Thus, the prefectural government selected the 1896 Sanriku Tsunami, which is the maximum in the recent 150 years, as the design tsunami. The height of the rebuilt levee is determined from the highest hazards among the tsunami, storm surges together with wind waves, and others. Storm surges are critical hazards for almost all the Sendai Bay Coast. The rebuilt levee height is determined to be $7.2 \mathrm{~m}$ above the mean sea level which includes the clearance of $1.0 \mathrm{~m}$.

Another requirement for the rebuilt is durableness of the levees. Mega tsunamis like the 2011 Tsunami would overflow the rebuilt levees again. However, destructive damage has to be avoided because of the costs and time for the re-rebuilt. This is the motivation of our study to find the destruction mechanism of the coastal levees, intending the contribution to the decision of the durable structure of the rebuilt levees.

Several prompt research that reported on the coastal damage (Suwa 2011, Tanaka etal.2011, Uda etal. 2011, Tanaka etal. 2011, Udo etal. 2011) could be referenced.
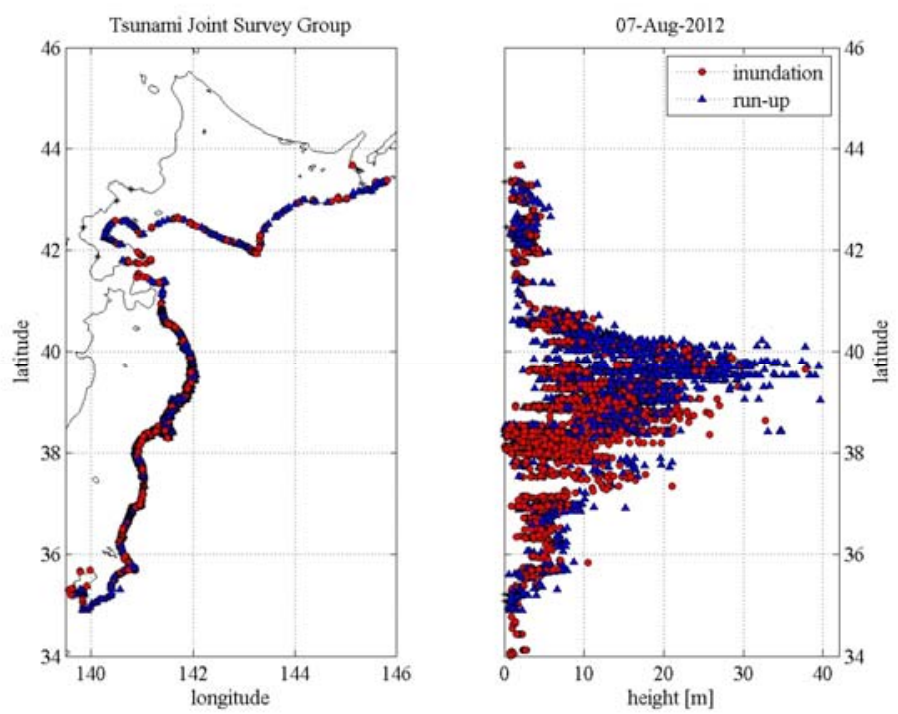

Figure 2. Inundation and run-up height of the 2011Tsunami. (The 2011 East Japan Earthquake Tsunami Joint Survey Group 2011) 


\section{METHODOLOGY}

We collected aerial photos before and after the tsunami from Geospatial Information Authority of Japan (GSI), the tsunami record and video from Tohoku Regional Development Bureau (TRDB) in MLIT. "Michinokugo” of TRDB's helicopter took off the Sendai Airport at 15:23 JST, when it was 37 minutes after the main shock and about 20 minutes before the inundation of the airport by the tsunami. It flew south along the Sendai Bay Coast and took a tsunami video. It enables us to know the tsunami behavior and the breaking process of the levees by referencing the tsunami records.

We also conducted a field survey. We measured the tsunami inundation depth and the tsunami scouring depth and width. We took photos on the breaking appearance of the levees.

Figure 3 shows a map of the Sendai Bay Area with some names referenced. Here the Yamamoto Coast in the south was most significantly damaged. The photos before and after the tsunami are shown in Photos 1 and 2 respectively. This coast is suffering from severe erosion and T shaped jetties were constructed as the countermeasure. Wave dissipation blocks were placed in front of the levees. The tsunamis breached the levees in many places and a coastal channel was formed behind the levees by the tsunami erosion.

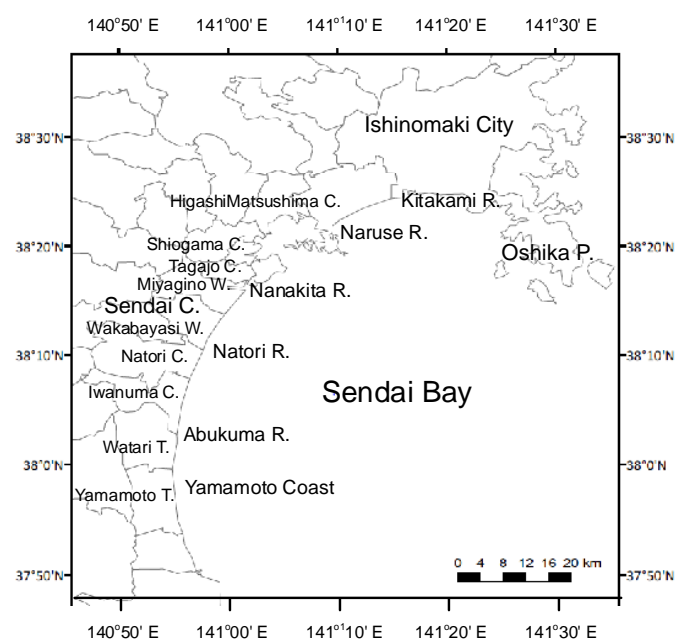

Figure 3. Sendai Bay area

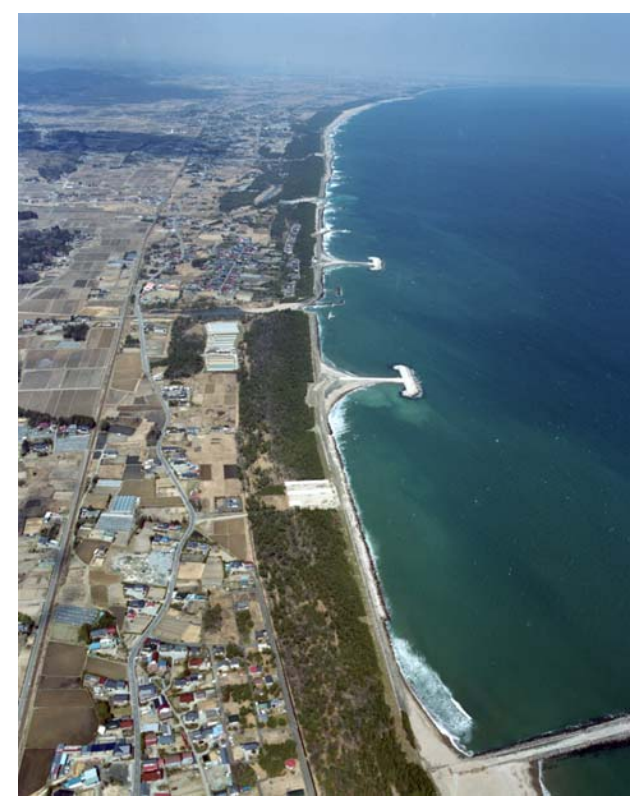

Photo 1. Yamamoto Coast before the tsunami taken by MLIT on March 2010

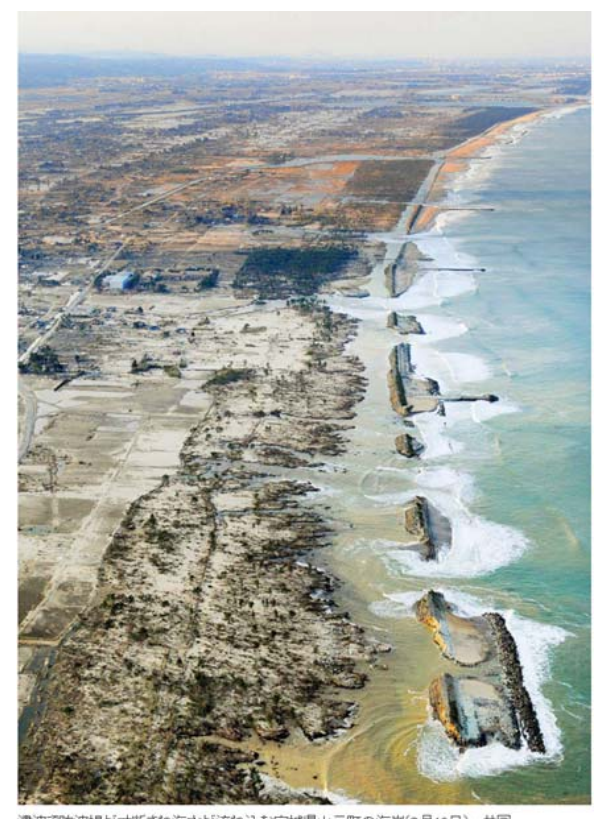

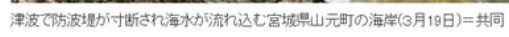

Photo 2. Yamamoto Coast after the tsunami taken by Kyodo News on March 19, 2011 


\section{TSUNAMI BEHAVIOR}

The tsunami behavior is described as the external conditions to break the levees. Figure 4 shows the tsunami record near the source measured by Port and Airport Research Institute (PARI) in MLIT. The first wave is the maximum wave with a sharp rise of the amplitude $6.5 \mathrm{~m}$. Then six waves followed with the amplitude less than $2 \mathrm{~m}$ and the period of 40 to 60 minutes. They are much smaller than the first wave and rise of the mean sea level is significant.

Figure 5 shows the tsunami record at Nobiru, $0.5 \mathrm{~km}$ upstream of the Naruse River mouth. The first wave is the maximum wave with the amplitude $6.6 \mathrm{~m}$ and highly sharp rise. This indicates the first wave run-up the river like a bore. The peak of the first wave appeared at 15:49 JST which is 63 minutes after the main shock. The tsunami propagation delayed to cross the shallow Sendai Bay.

Figure 6 shows the tsunami record at Abukuma-ozeki, $10 \mathrm{~km}$ upstream of the Abukuma River mouth. The first wave is the maximum wave with the amplitude $5.2 \mathrm{~m}$ and highly sharp rise too. The peak of the first wave appeared at 16:20 JST. If we subtract the travel time of 25 minutes from the river mouth to the Abukuma-ozeki, the estimated peak time at the coast is $15: 55$, which is 69 minutes after the main shock, and agrees with the descriptions by many residents who witnessed the tsunami.

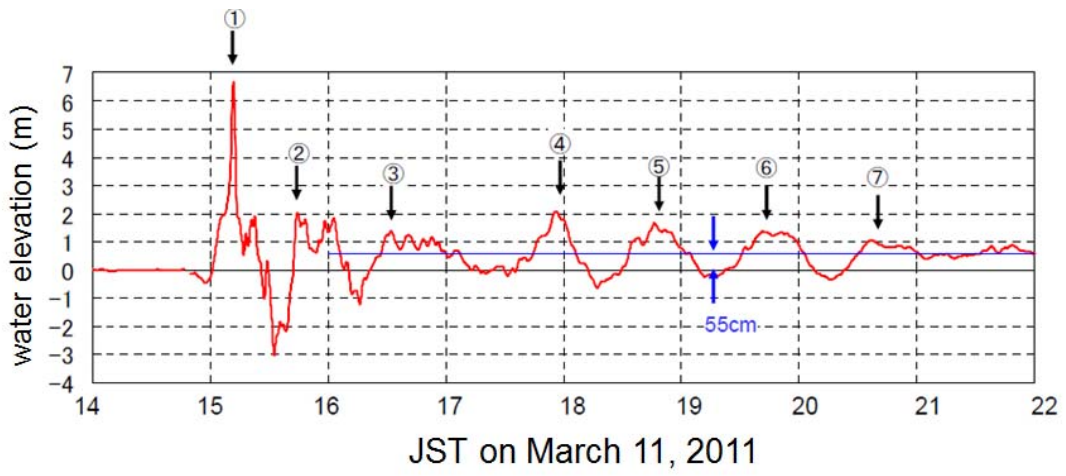

Figure 4. The GPS tsunami gauge record at $200 \mathrm{~m}$ depth off Kamaishi measured by PARI (http://www.pari.go.jp/files/items/3527/File/results.pdf)

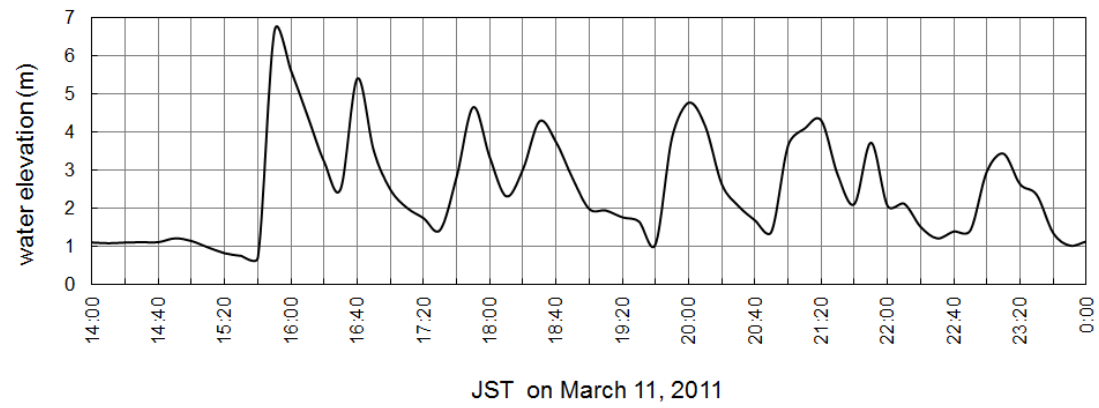

Figure 5. Tsunami record at Nobiru, $0.5 \mathrm{~km}$ upstream of the Naruse River mouth, measured by MLIT.

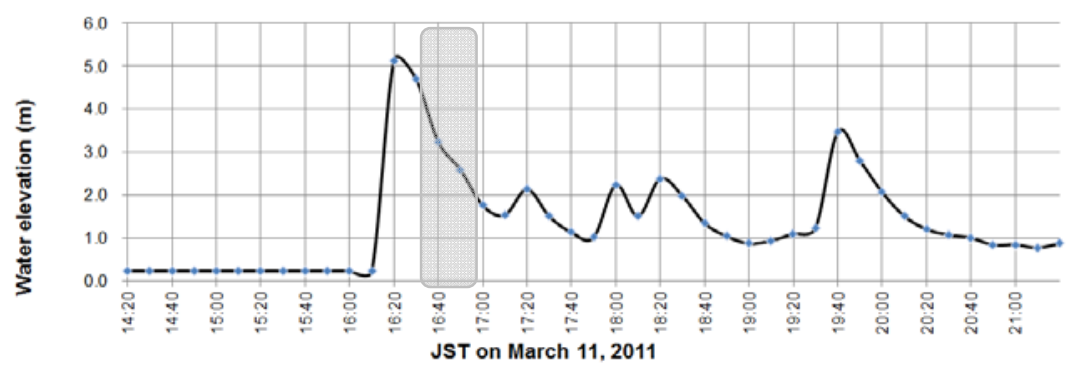

Figure 6. Tsunami record at Abukuma-ozeki, $10 \mathrm{~km}$ upstream of the Abukuma River mouth, measured by MLIT. The shade indicates the tsunami phase video-recorded from

“Michinokugo". 
The helicopter "Michinokugo" took a video on the tsunami behavior from Sendai at 16:10 JST to Yamamoto Coast at 16:35 JST. To synchronize the tsunami video to the tsunami record, we used the record of Abukuma-ozeki by shifting 25 minutes to estimate the tsunami record at the coast. The shade in Fig. 6 indicates that the tsunami video was taken when the surface elevation was decreasing after the first peak.

Photo 3 shows countless solitons which are a series of solitary waves and appear for long distance propagation in shallow water regions. Photo 4 shows breaking of solitons as they approached near the coast and a series of surges were hitting the coast.

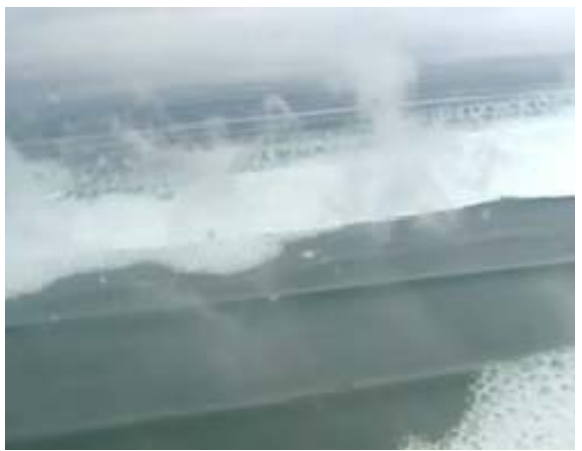

Photo 3. Countless solitons off the Natori Rivermouth, at 16:13 JST captured from "Michinokugo" video

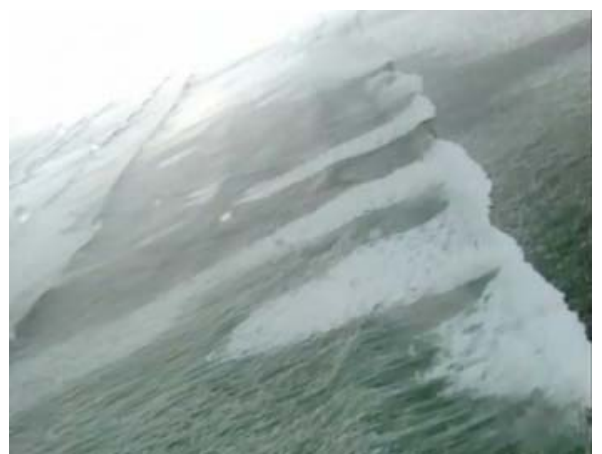

Photo 4. Breaking solitons off the Natori Rivermouth, at 16:14 JST captured from “Michinokugo" video

Here we summarize the tsunami features in the Sendai Bay as follows,

- The leading wave was the maximum wave with the amplitude of 6 to $7 \mathrm{~m}$. It can be treated as a progressive wave, because it is comparable to the tsunami near the source and the maximum inundation height of $15 \mathrm{~m}$ could be explained by the reflection.

- The front face of the leading wave was steep and like a bore. This agrees with the descriptions by many residents who witnessed the tsunami. Thus the front has high potential to give strong impact to the coastal structures.

- The rear face of the leading wave accompanied countless solitons and gave impact as a series of surges to the coast.

- The following waves are much smaller than the leading wave and could give less impact.

\section{DESTRUCTION PROCESS AND MECHSNISMS}

\section{Breach at the junction, case 1}

Photo 5 shows the levee breach at Fujitsuka, $2.55 \mathrm{~km}$ north of the Natori River mouth. Levee breach occurred at the junction of different type levees: upright solid concrete levee and mild slope levee. Rear side along the concrete levee and junction area are significantly eroded. A maintenance road and then pine tree woods existed behind the levees. The mild slope levee has structure such as soil mound armored by concrete blocks. Wave dissipation blocks had been placed in front of the two kinds of levees. Scatter of the armor and dissipation blocks is found behind the levees and in the woods.

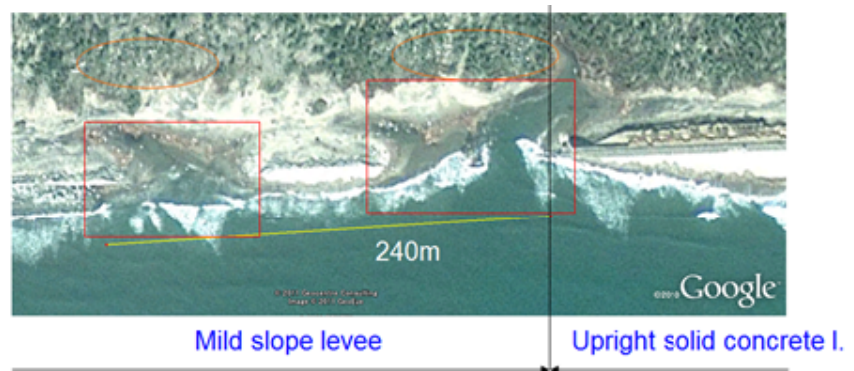

Photo 5. Breach at Fujitsuka. Google Earth image on March 14, 2011 
Photo 6 overlooks the breach point from the north. The deep erosion at the breach point was filled back soon. Photo 7 overlooks the concrete levee from the breach point. The levee had been footed with the depth more than $3 \mathrm{~m}$. However because of the significant erosion, the footing of the end concrete block disappeared and the block fell landward. The erosion behind the concrete levee is deeper towards the breach point. This indicates the erosion mainly caused by the return flow. Photo 8 shows scatter of the armor blocks in the pine tree woods. Photo 9 shows scatter of the wave dissipation blocks behind the mild slope levee.

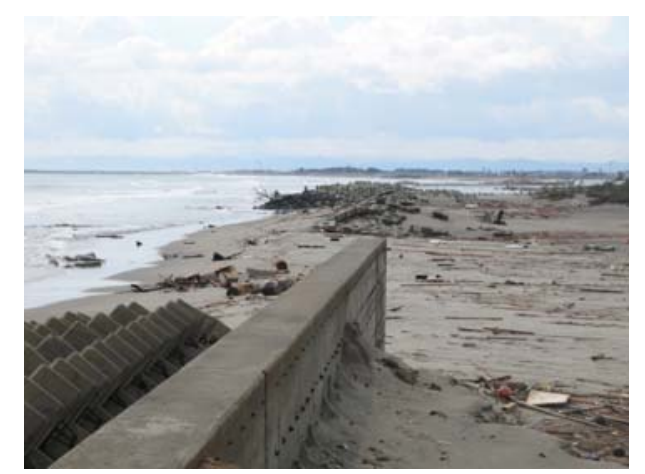

Photo 6. Overlook the breach point from the north photographed on March 26, 2011

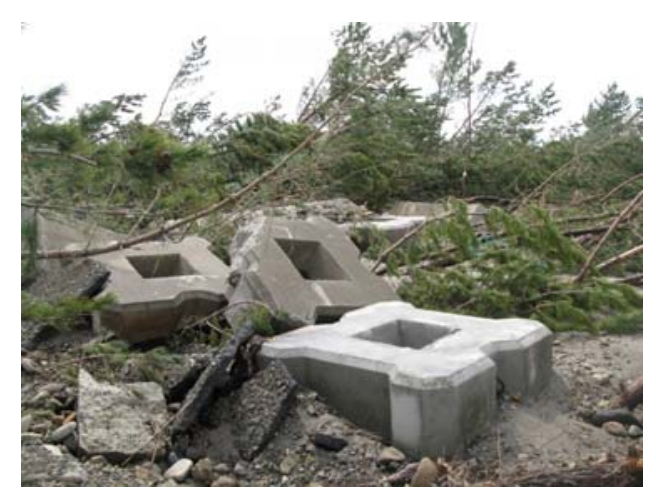

Photo 8. Scatter of the armor blocks in the woods

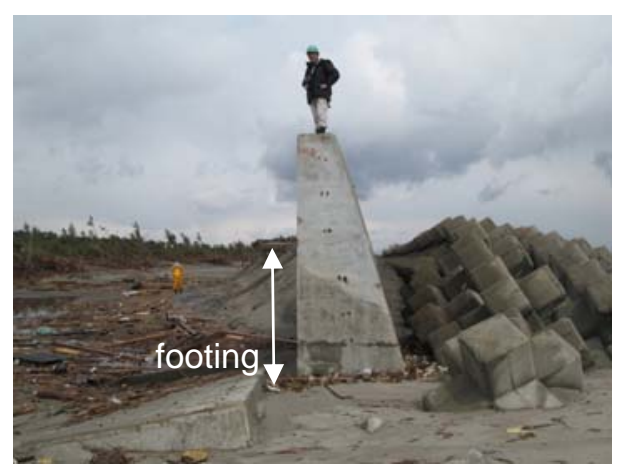

Photo 7. Overlook the conclete levee from the breach point

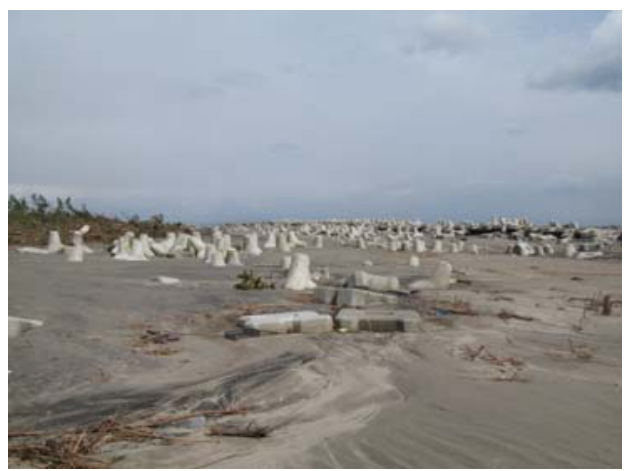

Photo 9. Scatter of the dissipation blocks behind the levee.

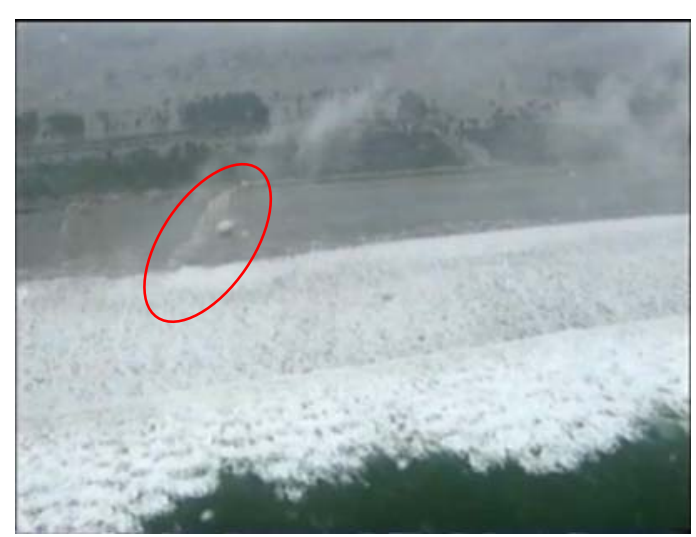

Photo 10. Return flow from the breach point at Fujitsuka at 16:14 JST, captured from "Michinokugo" video. Return flow from the breach point is circled.

Photo 10 shows a Fujitsuka point shot from "Michinokugo". A series of soliton surges approach to the coast while the encircled is the trace of the return flow from the breach point. This means that the junction was broken before this shot, convincingly by the surging bore of the leading wave.

Inclination of the trace to the south indicates dominancy of the return flow along the concrete levee.

Here we could summarize the destruction process at Fujituka point as follows, 
- The surging bore of the leading wave overtopped the two types of levees and broke the junction of the mild slope levee. The tsunami carried the armor blocks and wave dissipation blocks landward. Spilled water from the concrete levee fell down to the rear and scoured.

- The return flow along the rear side of the concrete levee accelerated itself by the confluence of the flow through the woods and increased erosion.

- High erosion at the junction removed the footing soil and the end concrete block turned landward.

\section{Breach at the junction, case 2}

Photo 11 shows the breach point at the Abukuma River mouth. It locates at the junction of the river levee and coastal levee. A newly formed channel behind the coastal levee continues to the breaching point and then to the eroded beach. Photo 12 shows broken coastal levee. The levees have structure that three sided concrete slabs cover the soil mound and the seaside slab is extended to a recurved parapet. The parapet was broken at several points which correspond to erosion streaks on the beach in Photo 11. Photo 13 shows the back side of the end block of the river levee. One block of the coastal levee was separated at the joints and completely lost. Photo 14 shows three sides of the river levee in which the river side covered by concrete blocks was not damaged at all for the overflow of the tsunami. Upright parapet at the top was blown away landward by the overtop. The land side covered by the grass was eroded deeply by the overflow and return flow.

Photo 15 shows the return flow at the Abukuma River mouth taken from "Michinokugo". We can see intense return flow issued from the breach point and large eddies of turbid water which extends wide and far from the levee. Narrow streaks of the return flow issue also from the break points of the recurved parapet as mentioned for Photo 11. Judging from the extension of the turbid water, the break of the parapet occurred fairly before the shot of "Michinokugo", again convincingly by the surging bore of the leading wave.

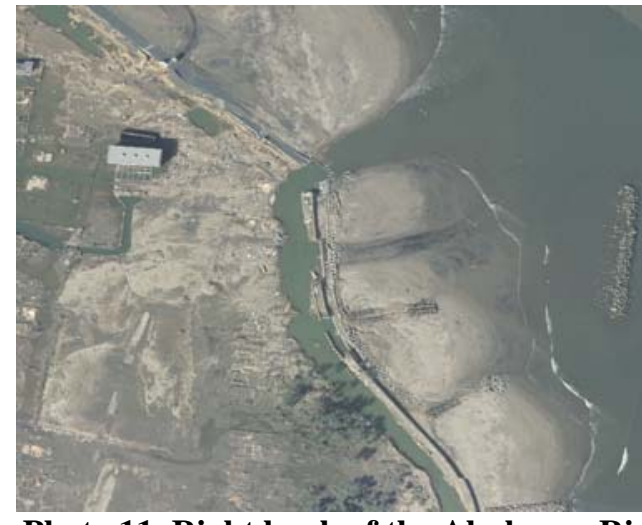

Photo 11. Right bank of the Abukuma River mouth, photographed on March 12, 2011 by GSI.

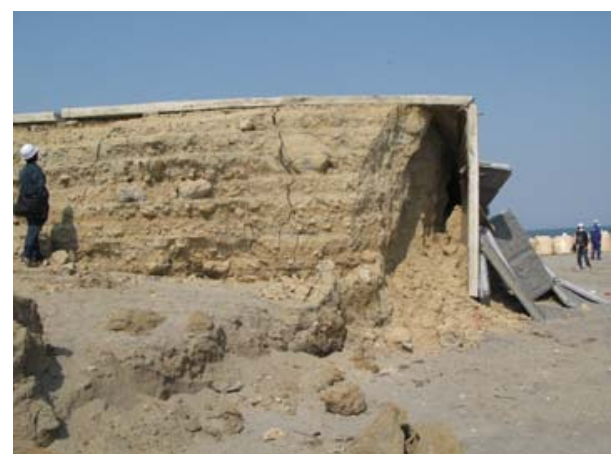

Photo 13. End section of the river levee.

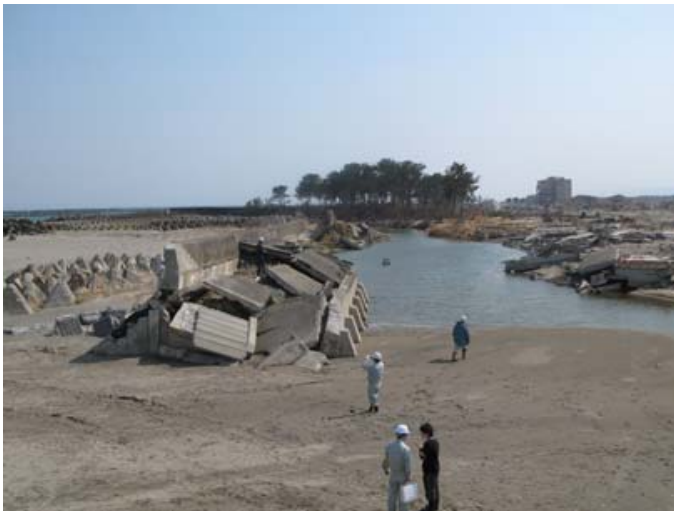

Photo 12. Broken coastal levee and newly formed channel

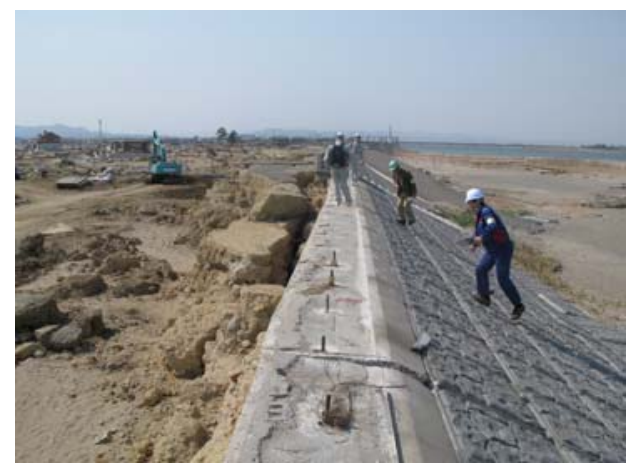

Photo 14. Three sides of the river levee. 


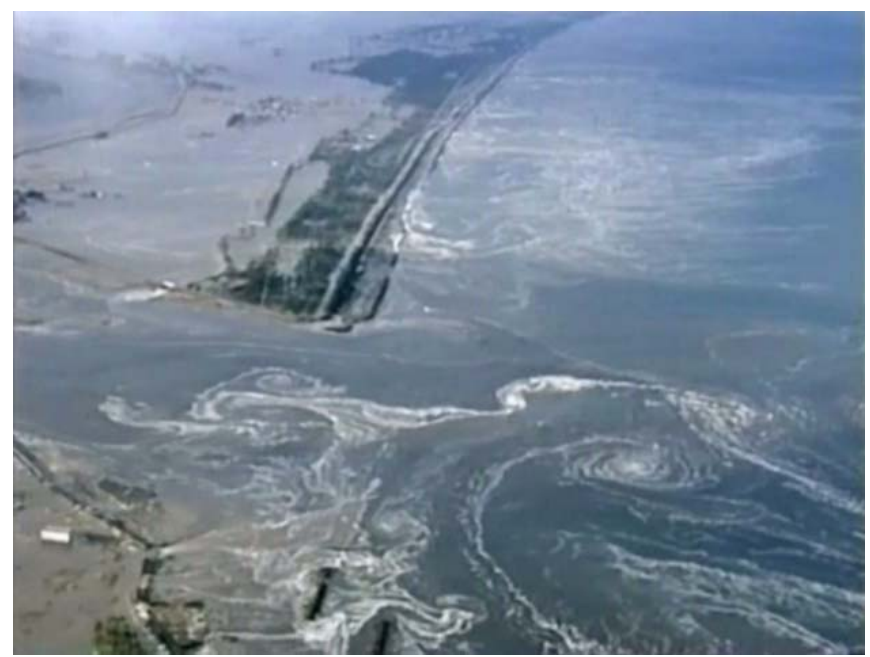

Photo 15. Return flow in the sea issued from the breach point, the right bank of the Abukuma River mouth, at 16:33 JST, captured from "Michinokugo" video.

Here we could summarize the destruction process at the Abukuma River mouth as follows,

- The surging bore of the leading wave run-up the riverside slope of the river levee, blew the upright parapet away and eroded the land side of the levee. The bore also hit the recurved parapet of the coastal levee, broke it at several points and intruded into the land.

- Huge amount of seawater on land delivered by the overflow soon started to return back to the sea through the gaps of the broken parapet of the coastal levee. The junction block of the coastal levee was easily moved by the water pressure due to the joints.

- Because the lower structure of the coastal levee remained at the other part, the return flow along the rear side of the levee headed to the breach point by accelerating itself and eroding the bottom. This is the cause of the turbid water and channel formation.

\section{Breach at the Yamamoto Coast}

As mentioned on Photos 1 and 2, the Yamamoto Coast was most violently destructed. Photo 16 shows the aerial photo of the southern Yamamoto Coast on March 12, 2011. Encircled places on the photo indicate massive erosion. The places agree with the channels shown in Fig. 7 of the topographic map. This indicates that the huge amount of sea water delivered by the tsunami returned to the sea by concentrating to the channels and eroding the sides and bottom.

Photo 17 and Fig. 8 show similar conditions of the middle Yamamoto Coast. Swamps and old channels which had dead ends before the tsunami were also the targets of the return flow concentration. The flow extended the dead ends by the erosion while breaking the levee and further extending to the sea. After the tsunami, wide and long inlets were formed.

The coastal levees in the southern Yamamoto Coast have structure that three side concrete slabs with a recurved parapet cover the soil mound. Wave dissipation blocks were thickly and highly placed in front of the levees, because storm waves give high impact on the levees with no beaches and deepened shoreline. A typical coastal levee in the northern Yamamoto Coast has structure that the seaside and landside of the soil mound are covered by concrete blocks embedded into concrete lattices and the top is paved by asphalt without any parapet.

Photo 18 shows breaking of the recurved parapet on the southern Yamamoto Coast. These parapets are much thicker than these of the coastal levees at the Abukuma River mouth and were protected by the wave dissipater blocks. However, they could not keep the shape against the tsunami impact.

Photo 19 shows the backside of the levee. The top and landward concrete slabs were broken and scattered.

Photo 20 shows the seaside of the levee on the northern Yamamoto Coast. Most of the concrete blocks embedded in the lattices remained, however, in the rear side most of the blocks especially in the lower parts were sucked out and scattered landward. The lattices were also deformed and broken in some places. It is deduced that the structures to block the tsunami impact were broken in most cases and sloped structures on which the tsunami passed through were less broken. 

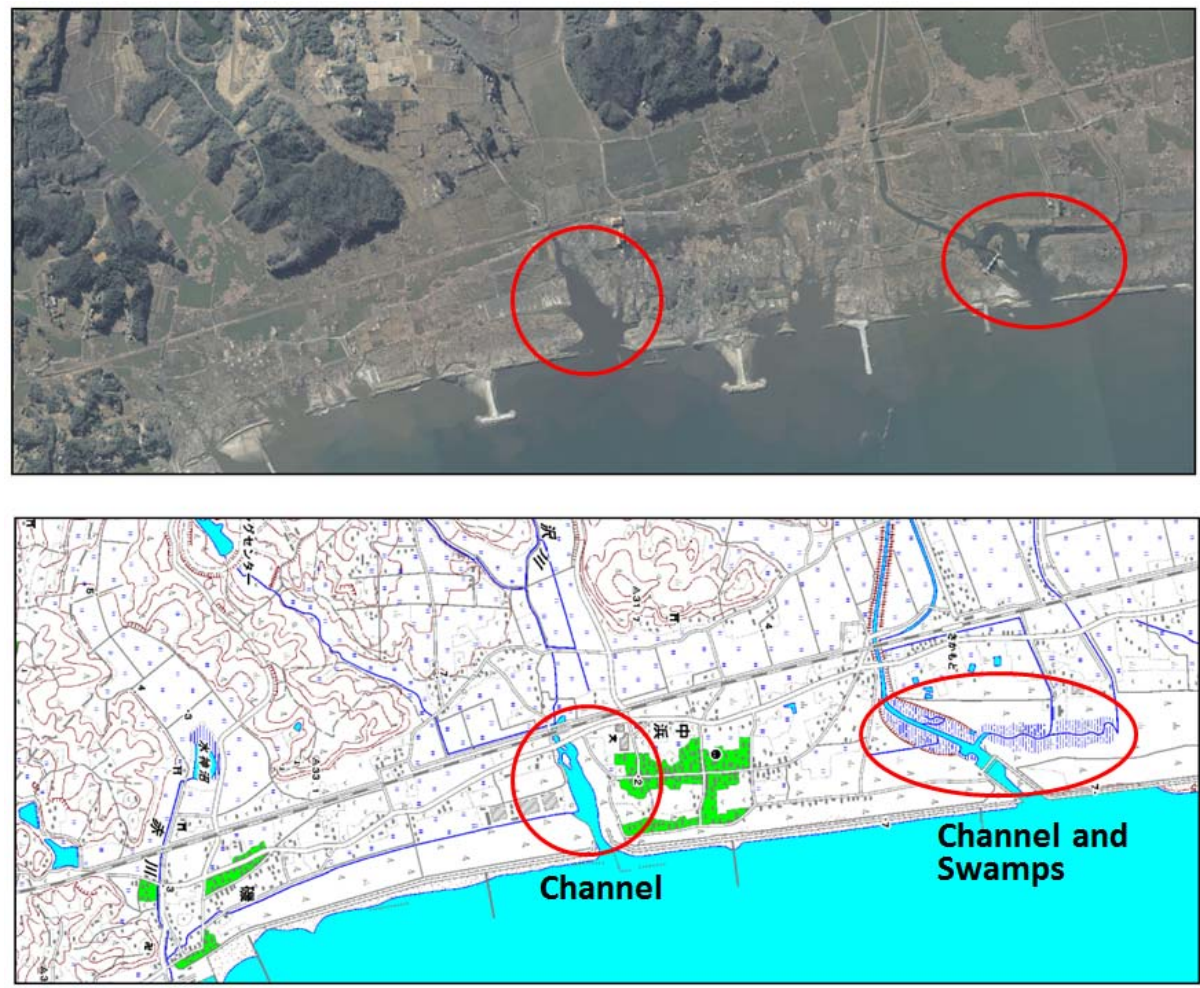

Photo 16 (top). Aerial photo of the southern Yamamoto Coast on March 12, 2011 taken by GSI. Figure 7 (bottom). Topographic map of the same region measured in 2009 by GSL.
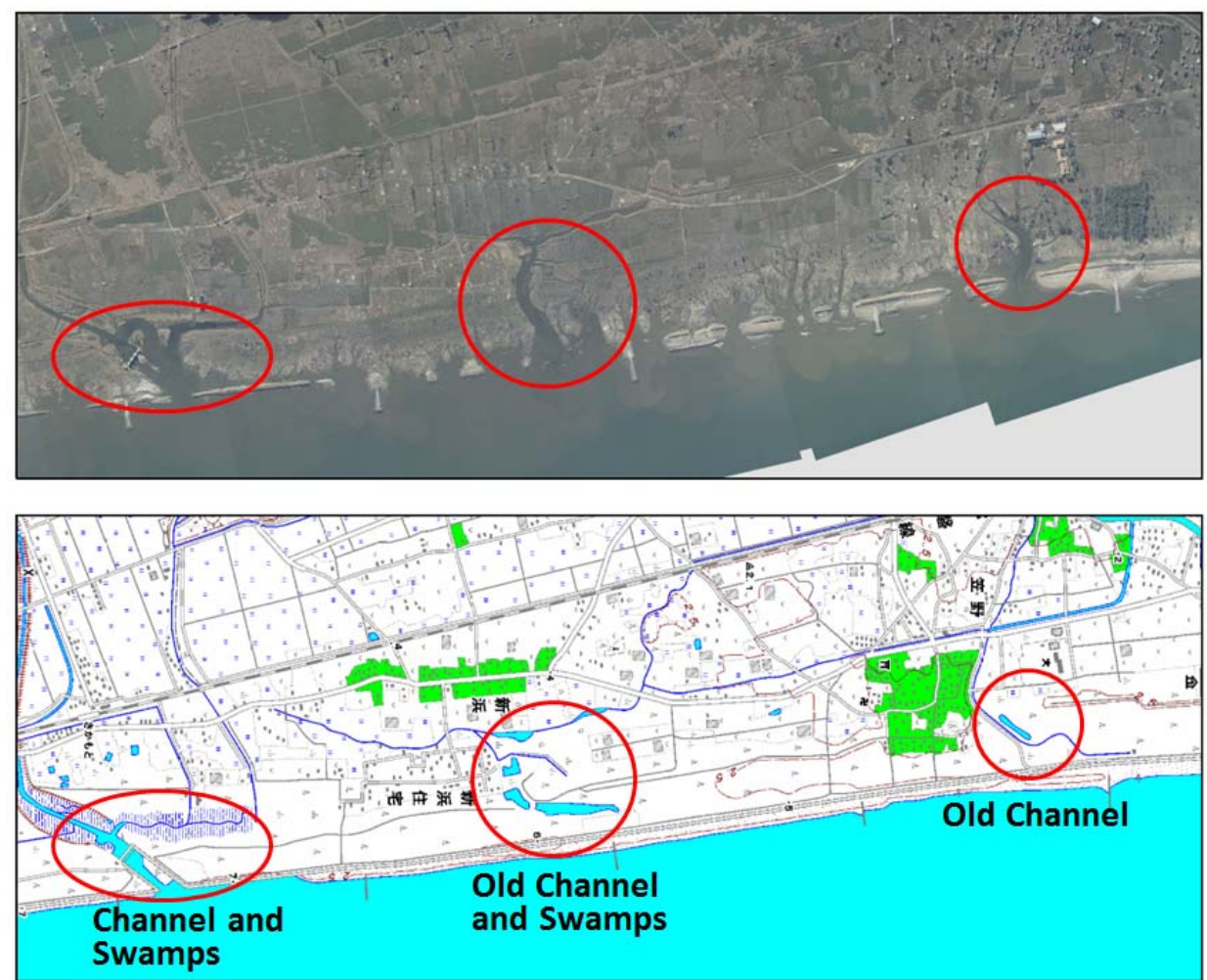

Photo 17 (top). Aerial photo of the middle Yamamoto Coast on March 12, 2011 taken by GSI. Figure 8 (bottom). Topographic map of the same region measured in 2009 by GSI. 


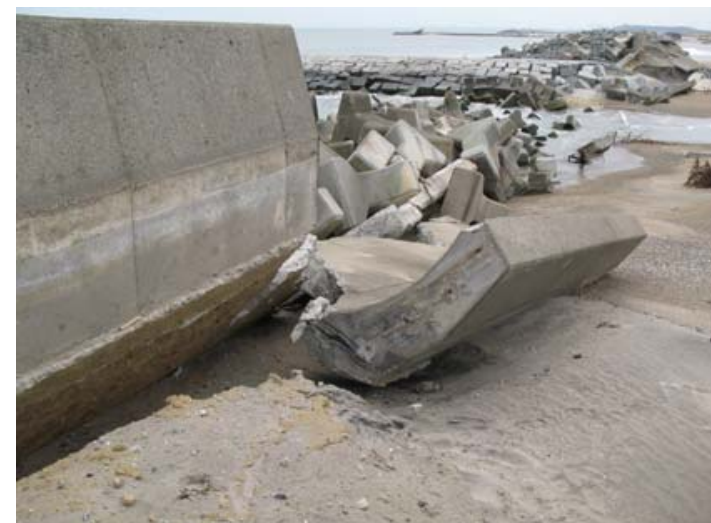

Photo 18. Breaking of recurved parapet, southern Yamamoto Coast.

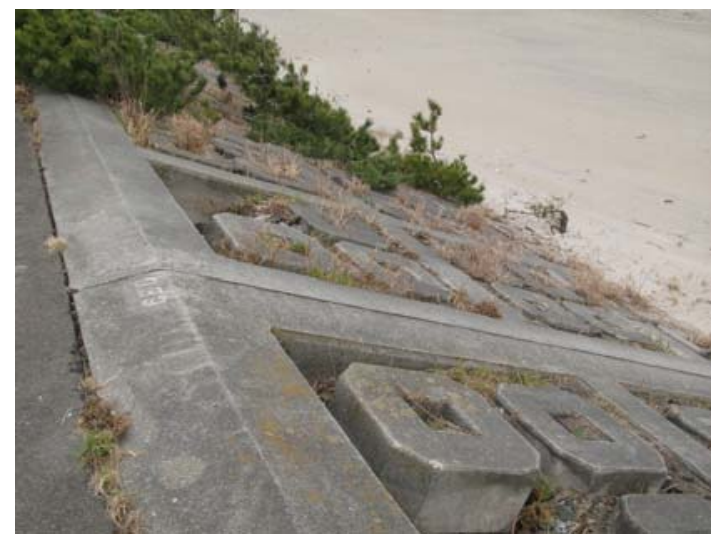

Photo 20. Seaside armor blocks of the levee, northern Yamamoto coast.

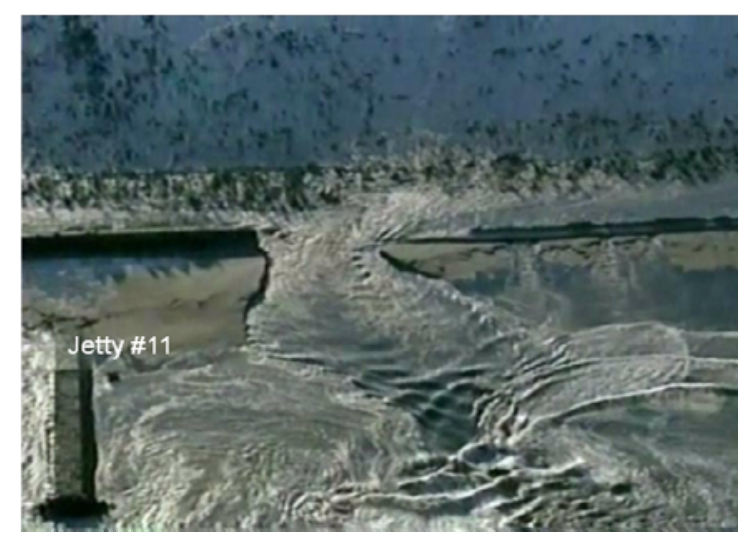

Photo 22. Return flow from the break point at 16:35 JST, March 11, shot from "Michinokugo"

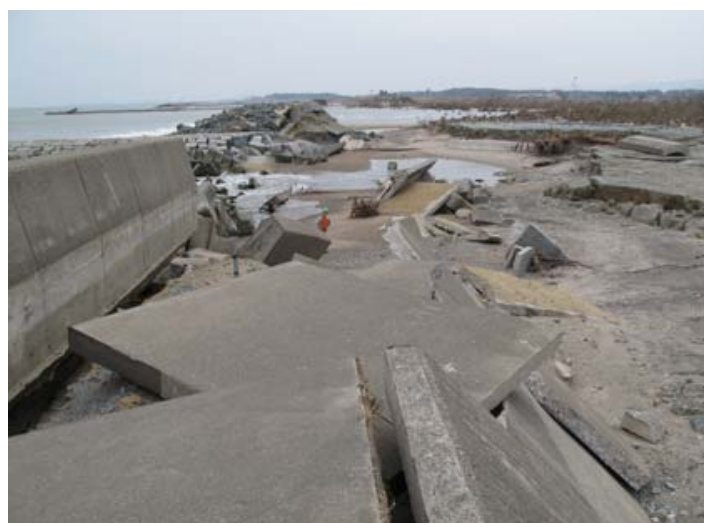

Photo 19. Breaking of the top and landside concrete slabs, southern Yamamoto Coast.

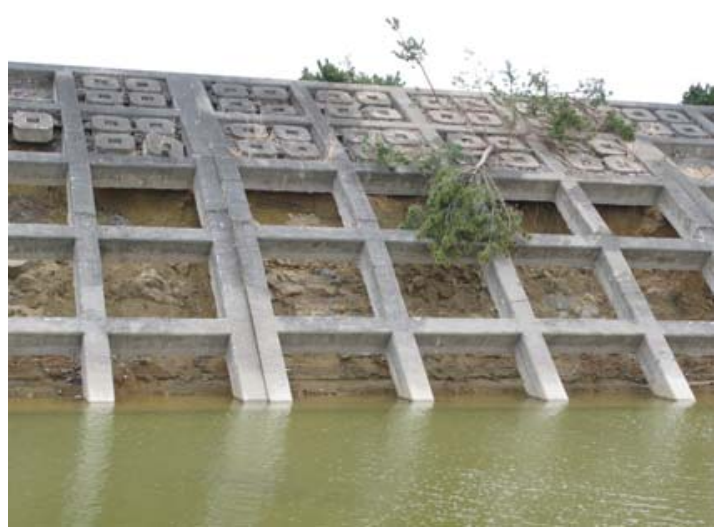

Photo 21. Landside armor blocks of the levee, and a created channel, northern Yamamoto Coast.

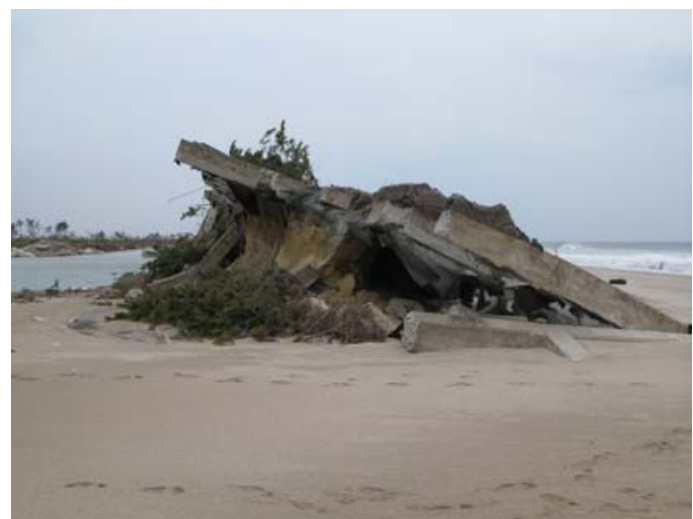

Photo 23. Destructive erosion of the levee at the break pint.

Photo 22 shows return flows along the rear side of the levees and the flows are merged at the break point with the flow through the pine tree woods. The flow concentration causes high erosion to wash the levees from the basement away as shown in Photo 23.

Photo 24 shows the southern Yamamoto Coast shot from "Michinokugo" at 16:39 JST. We can see several segments of the levee above the sea surface. The other part of the levee is submerged. This indicates that the other part of the levee was broken and corresponds to the broken parapet. Widely spread large eddies of turbid water issue from the submerged levee and this suggests again that the parapet was broken by the impact of the surging bore of the leading wave. 


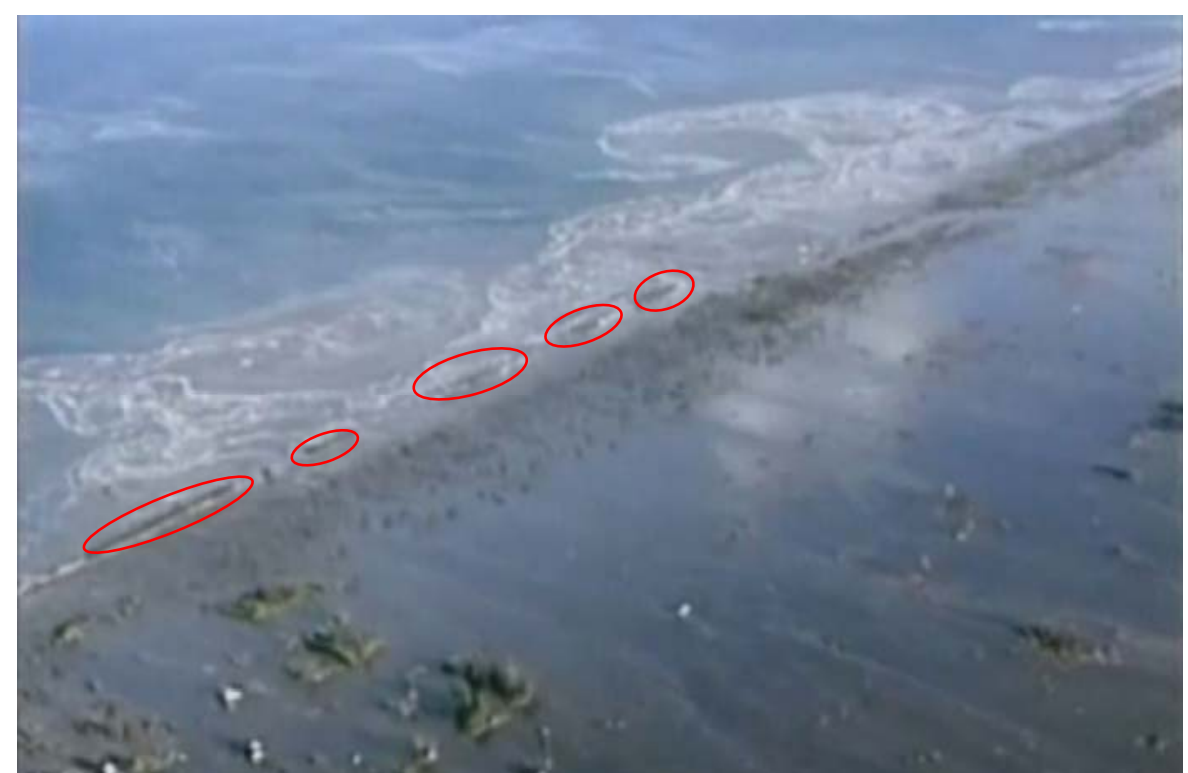

Photo 23. Return flows from the break points on southern Yamamoto Coast, at 16:39 JST, March 11, shot from "Michinokugo". Upper left of the photo is the sea. Encircled objects are levees above the sea surface.

Here we could summarize the destruction process on the Yamamoto Coast as follows,

- On the southern Yamamoto Coast, the surging bore of the leading wave broke the recurved parapets, top and landside slabs, while on the northern coast which has moderate width of beaches, the bore ran up the seaside slope of the coastal levees without giving significant damage, overtopped, and then fell to the lower part of the landside levee by blowing the concrete blocks and breaking the concrete lattices in some places.

- Huge amount of seawater on land delivered by the tsunami soon started to return back to the sea by concentrating in two ways. One is the concentration to the existing or old channels and swamps, while the other is the concentration to the levees broken by the surging bore. The former created long and wide water body called "tsunami bay" by the strong current concentration and erosion. The latter created long water body called "tsunami channel" along the rear side of the levee. The break point of the levee led to a breach.

\section{CONCLUSIONS}

We find two step destruction mechanisms of the coastal levees on the Sendai Bay Coast hit by the 2011 Tsunami as follows,

1. Damage by the impact of the leading surge front: scatter of the wave dissipation blocks at the front side, breaking of parapets at the levee top, breaking of slabs or concrete lattices, scatter of covering blocks, or soil erosion at the back site.

2. Erosion by the return flow concentration to the existing or old channels and swamps, the breaking points due to the article1, resulting in tsunami bay, tsunami channel, and breach of the levees. The junctions of the levee type were prone to be the target of the flow concentration and then to be breached.

\section{ACKNOWLEDGMENTS}

This study was supported by the Specific Project Grant 2012 by IRIDeS and by Grant-in-Aid for Scientific Research (B), 23360193. These supports are gratefully acknowledged. The authors also wish to express their gratitude to Ms. Yuriko Takeda for the excellent GIS analysis. 


\section{REFERENCES}

The 2011 East Japan Earthquake Tsunami Joint Survey Group. 2011. Nationwide Field Survey of the 2011 Off the Pacific Coast of Tohoku Earthquake Tsunami, Journal of Japan Society of Civil Engineers, Series B, Vol. 67 , No.1, 63-66. (http://www.coastal.jp/tsunami2011/)

Nanayama F., K. Satake, R. Furukawa, K. Shimokawa, BF. Atwater, K. Shigeno, and S. Yamaki. 2003. Unusually large earthquakes inferred from tsunami deposits along the Kuril trench, Nature, 7;424(6949), 660-663.

Satake, K., Y. Sawai, M. Shishikura, Y. Okamura, Y. Namegaya, and S. Yamaki. 2007. Tsunami source of the unusual AD 869 earthquake off Miyagi, Japan, inferred from tsunami deposits and numerical simulation of inundation, American Geophysical Union, Fall Meeting 2007.

Suwa Y. 2011. Characteristics of the coastal structures and the hinterlands damaged by the tsunami. http://www.nilim.go.jp/lab/bbg/saigai/h23tohoku/houkoku/happyou/2-4.pdf

Tanaka H., A. Mano, and K. Udo. 2011. Beach morphology change induced by the 2011 Great East Japan Earthquake Tsunami, Proceedings of Coastal Engineering, 67-2, 571-575.

Tanaka H., N.X. Tinh, M. Umeda, R. Hirano, E. Pradjoko, A. Mano, K. Udo. 2012. Coastal and estuarine morphology changes induced by the 2011 Great East Japan Earthquake Tsunami, Coastal Engineering Journal, 54-1, 1250010(25).

Uda T., and T. Minami. 2011. Great East Japan Earthquake Tsunami, Yamamoto Town, http://pwrcnagisa.jp/pdf/Miyagi_07.pdf

Udo K., D. Sugawara, H.Tanaka, K.Imai, A.Mano.2012. Impact of the 2011 Tohoku Earthquake and Tsunami on beach morphology along the northern Sendai Coast, Coastal Engineering Journal, 541, 120009(15). 